\title{
Cicadatra lorestanica, a new species of cicada from Iran (Hemiptera: Cicadidae)
}

\begin{abstract}
Cicadatra lorestanica, sp.n. is described from western Iran. The species was collected in oak woodlands. The song is a continuous series of sound pulses produced at a rate of $917 \pm 68 \mathrm{~Hz}(\mathrm{n}=4)$ with peak frequency determined to be $11.391 \pm 0.099 \mathrm{kHz}(\mathrm{n}=4)$.

Riassunto - Cicadatra lorestanica, a new species of cicada from Iran (Hemiptera: Cicadidae)

Viene descritta Cicadatra lorestanica, raccolta in Iran occidentale soprattutto su Quercus spp. e in alcuni casi su Crataegus. E' stato registrato il suo frinire, che è costituito da una serie continua di pulsazioni a $917 \pm 68 \mathrm{~Hz}(\mathrm{n}=4)$ con una frequenza di picco pari a $11.391 \pm 0.099 \mathrm{kHz}(\mathrm{n}=4)$.
\end{abstract}

Key words: Hemiptera Cicadiadae, new species, calling song, Iran.

\section{INTRODUCTION}

The oldest publication on the Iranian cicadas was Dlabola (1960) in which he described two new species from Iran. Further cooperation between the Hayk Mirzayans Insect Museum and a scientific group form the former Czechoslovakia made significant progress in the knowledge of Iranian cicadas (Dlabola and Heller 1962; Dlabola 1970, 1979, 1981, 1987; Mirzayans et al. 1976; Mirzayans 1995). There were some other records published by Iranian researches during those years and others that were mainly on cicadas with economic importance in jungles and agricultural ecosystems (Farahbakhsh 1961; Babaii 1967; Behdad 1991; Abaii 2000). These previous works plus a few recent publications (Schedl 2003; Mozaffarian 2008; Gogala and Schedl 2008; Mozaffarian and Sanborn 2010) showed the presence of 38 cicada species inhabiting Iran. Of theses 38 species, 16 had been originally described from Iran with sound analysis being provided with the description for only for one species (Tettigetta golestani Gogala \& Schedl, 2008).

This work continues the process of identifying new collected specimens and describing previously unknown species in the Hayk Mirzayans Insect Museum. The region where these specimens were collected was then visited in an effort to obtain biological information about the species. 


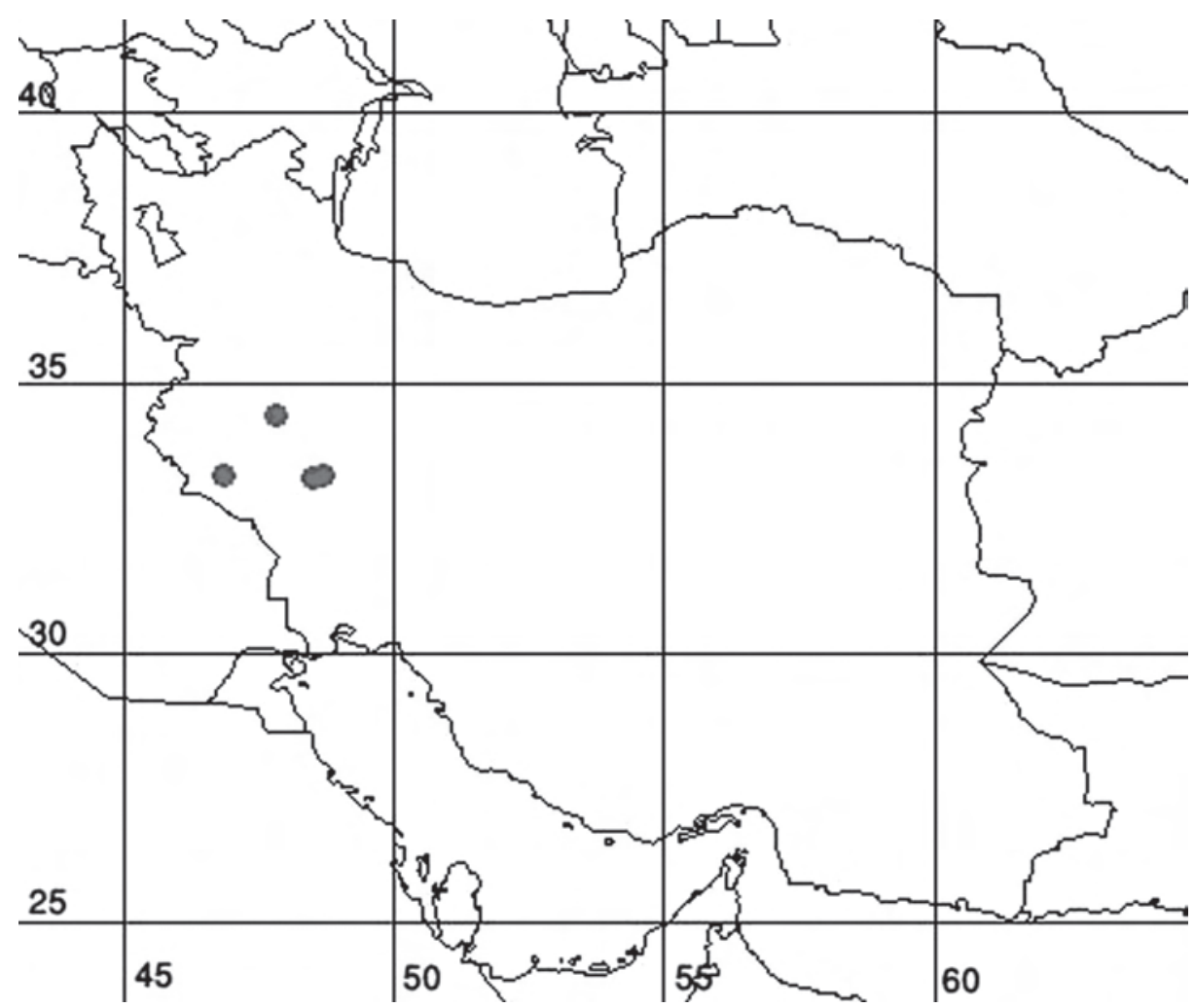

Fig. 1 - Collecting sites of Cicadatra lorestanica.

\section{MATERIALS AND METHODS}

The examined specimens were mainly collected from oak (Quercus sp) woods (Fig. 7) in Lorestan province in western Iran (Fig. 1) during summer 2009 as well as some older specimens deposited in Hayk Mirzayans Insect Museum (HMIM), Iranian Research Institute of Plant Protection. Measurements were made using Vernier calipers and anatomical terminology follows Mould (2005). Type material is deposited the HMIM and also in the Sanborn collection (AFSC).

Calling songs were recorded from active specimens on oak trees, using a Zoom Handy Recorder H4, at a sampling rate of $96 \mathrm{KHz}$ and 24 bit resolution. The microphone and recorder have a $\pm 3 \mathrm{~dB}$ sensitivity to about $11-12 \mathrm{kHz}$ whereupon the frequency response decreases. Sound files were analyzed using RavenPro 1.3 and a Macintosh computer. 


\section{RESULTS AND DISCUSSION}

Cicadatra lorestanica Mozaffarian and Sanborn, sp. n.

\section{Type material}

IRAN. Holotype: male, Lorestan province, Nujian, N: 33 16' 4.2” E: 48 31'18", 24.Jul.2009, Collector: Mozaffarian/ Nematian (HMIM). Paratypes: 1 male, Hamedan province, Nahavand, Gamasiab, 1750m, N: 34² 24'39' E: 47 49' 6.3” 7.Aug.1997, Collector: Barari/Mofidi (HMIM); 2 males, Ilam province, Meymeh Rd., N: 33 18' 33.5' E: 46 50' 17.0", 27.Jul.2006, Collector: Hajesmaiilian (1 each HMIM and AFSC); 1 male, Ilam, Meymeh Rd., Malekshahi, 1461m., N: 32²2' 23” E: 46 44’ 21.5’, 27.Jul.2006, Collector: Hajesmaiilian (HMIM); 8 males, Lorestan province, Nujian, 24\&22 Jul.2009, N: 33 16' 4.2" E: 48 31' 18", Collector: Mozaffarian/ Nematian (HMIM); 1 male, Lorestan province, Nujin Rd., 2024m, N: 33 15' 59.6” E: 48³1' 11.0”, 19.Jul.2006, Collector: Hajesmaiilian (HMIM); 2 males, Lorestan province, Sepid dasht Rd., Grit village, $1773 \mathrm{~m}$, N: $33^{\circ} 18^{\prime} 13.9^{\prime}$ 'E: 48 42' 55.1”, 22 .Jul.2006, Collector: Hajesmaiilian (1 each HMIM and AFSC).

\section{Etymology}

The species is named for the province of western Iran in which the holotype was collected.

\section{Description}

All collected specimens were male. The only female seen could not be captured but was observed to have a similar appearance to the males.

Coloration. General color of body black with brown markings and white pile.

Head (Figs. 2, 3). Head black with white pile particularly on the posterior edge. Head including eyes as broad as pronotum. Eyes brown, varying from light to dark in different specimens. Ocelli orangish. Postclypeus shiny black with light (whitish or brownish) semicircular lateral region and scattered white pile. The relative size of dark and light area varies in paratypes. Postclypeus with a central sulcus and obvious transverse grooves. Anteclypeus shiny black with rather dense white pile laterally. Gena and lorum black with dense white pile. Lorum edged with brown in some paratypes. Rostrum light brown at base, darker towards apex. Labium with sparse white pile laterally and on apex. Scape dark brown or black with light brown ring distally, antennae fading to light brown and yellow towards apex. Supra-antennal plate not reaching eyes, black with a light band in middle.

Thorax (Figs. 2,3). Pronotum with median black biconcave mark containing a light brown median fascia, two small yellow patches posteriolateral to median fascia and two large brown patches on anteriolaterad disc. Black mark continues around disc in ambient fissure and across lateral pronotal collar to the lateral angle. Paramedian and lateral fis- 


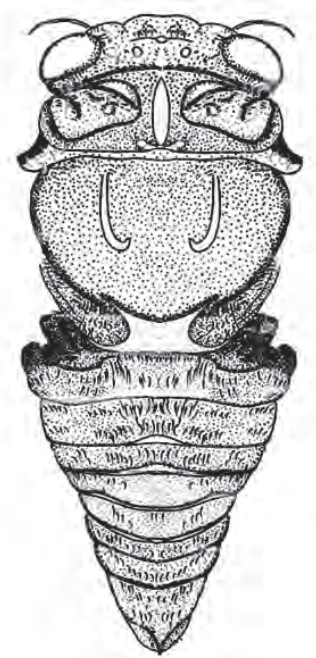

Fig. 2 - Cicadatra lorestanica: dorsal view of the body.

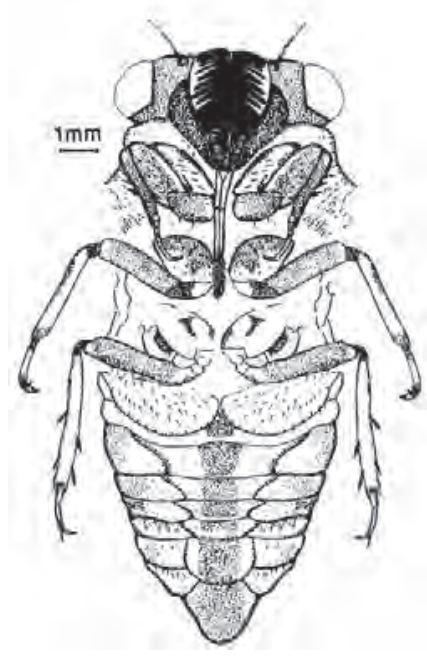

Fig. 3 - Cicadatra lorestanica: ventral view of the body

sures variably marked with black. Pronotal collar light brown with black lateral angles. White pile present on ambient, paramedian and lateral fissures and some scattered pile on disc, heavy in some paratypes. Mesonotum shiny black or dark brown, with light brown J-shaped pattern along parapsidal suture, anterior black region may present as four obconical spots on castaneous background in some paratypes. Cruciform elevation light brown medially, darkening to black in anterior arms. Metanotum light brown. Thoracic sternites light yellow with rather dense white pile. Some paratypes with dark markings on basisternum 2, epimeron 2, katepimeron 2, and episternum 3.

Legs (Fig. 3). Fore coxae brown with black and light yellow longitudinal areas. Middle coxae brown with lighter areas and white pile laterally. Hind coxae light brown with darker areas and few scattered pile on inner lateral and middle surface. Fore and middle trochanters dark brown with a light area at base with white pile. Hind trochanters brown with few scattered pile. Fore femorae dark brown with white pile and light areas on lateral edges and apex with slightly angled primary spine, erect secondary spine and a small angled apical spine. Middle femorae dark brown with a yellow area at apex and white pile. Hind femora brown with yellow area on base and apex. Fore tibiae brown, lighter at the base and darker towards the apex. Middle tibiae light brown with white pile and darker area near the junctions with femur and tarsus. Hind tibiae yellow with five brown tibial spurs and sparse white pile. Tibial spurs and combs brown, darker towards their apexes. Tarsi in fore legs brown, in middle legs yellow with brown areas at base and apex and in the hind leg yellow with brown apex. Claws brown darker towards the apex.

Wings (Fig. 4). Fore wings hyaline with brown venation and no infuscation. Brown color of venation becomes darker in basal part of costal vein, node and base of anal vein $2+3$. Fore wing basal cell heptagonal, cubitus anterior and median veins originate 


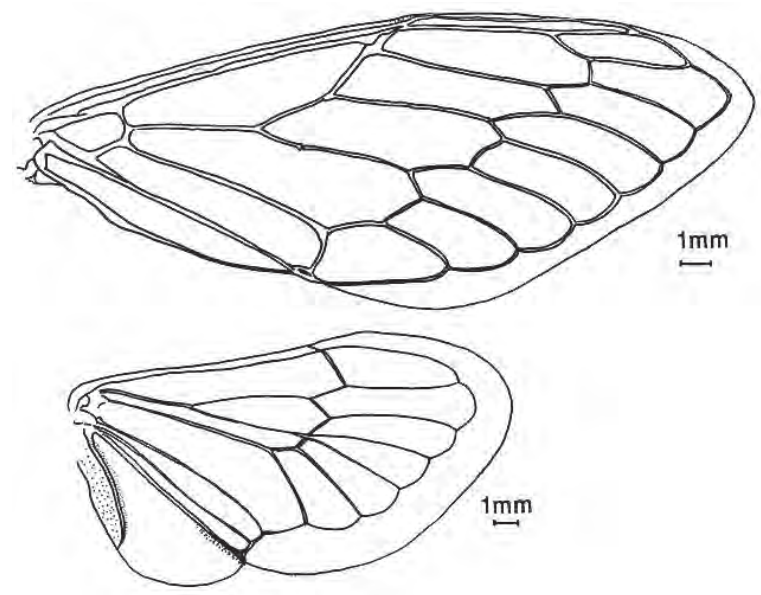

Fig. 4 - Cicadatra lorestanica: fore and hind wing.

separately. Cubitus posterior and median veins closer at base than cubitus anterior and cubitus posterior. Cubitus posterior and anal veins not fused at base or apex but fused medially. Fore wing with 8 apical cells, reduced to 7 in some paratypes. Basal membrane of fore wing hyaline. Hind wing hyaline with light brown venation. Anal vein 3 much darker than others in some specimens. Light brown infuscation around anal veins 2 and 3 . Hindwing with 6 apical cells. Radius posterior and median veins fused at base.

Operculum (Fig. 3). Male opercula light yellow with brown spot on lateral base and rather dense white pile, rounded, approaching one another but not meeting medially. Brown spot extends onto body of operculum in one paratype. Meracanthus triangular, light yellow with brown spot on base.

Abdomen (Figs. 2, 3). Abdominal tergites dark brown with white pile more or less located near the anterior edge of each tergum. Tergites 2 to 7 with a light area on posterior median part. Timbal cavity exposed. Timbal cover incomplete, black or dark brown with white pile. Timbal with 11 ribs. Abdominal sternites dark brown, epipleurites dark or light brown.

\section{Male genitalia (Figs. 5, 6).}

Male pygofer dark brown or black with scattered white pile, distal shoulder pointed, upper lobe of pygofer a finger-like extension. Basal lobe of pygofer appears as a short projection beneath the upper lobe. Uncus very short. Claspers long and straight, close to each other at base, angled laterally distally. Aedeagus heart shaped at base. Penis with a curved bifold sclerized hook-like and two lateral spine-like appendages.

Measurments (mean [range] in mm: $\mathrm{n}=16$ males). Length of body: 16.37 (14.2- 

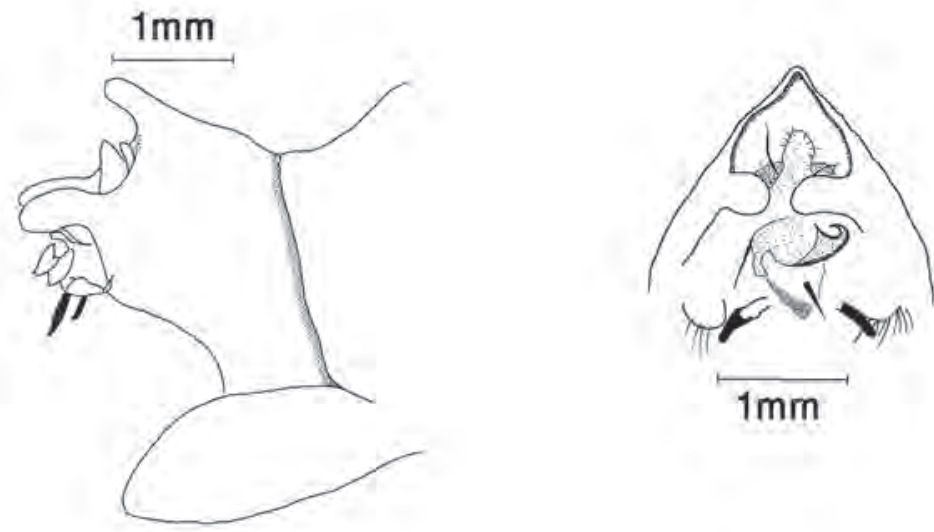

Fig. 5 - Cicadatra lorestanica: pygofer in lateral and ventral view

17.46. Length of fore wing: 20.84 (19.1-22.46). Width of fore wing: 7.395 (6.50-8.72). Width of head including eyes: 5.67 (5.14-6.00). Length of abdomen: 8.42 (7.26-9.42).

\section{Diagnosis}

The new species Cicadatra lorestanica is rather similar to Cicadatra ramanensis Linnavuori, 1962, Cicadatra hyalina (Fabricius, 1798) and Cicadatra vulcania Dlabola $\&$ Heller, 1962. The pygofer in the new species is very similar to C. ramanensis but the
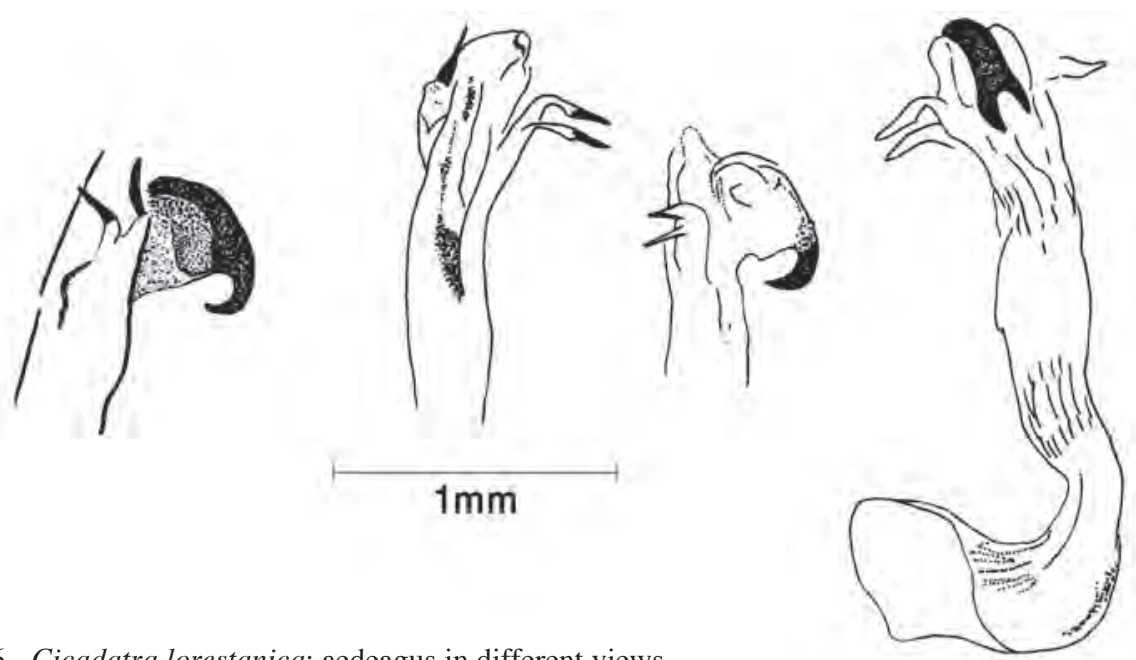

Fig. 6 - Cicadatra lorestanica: aedeagus in different views. 
penis has many fewer short apical appendages and the body size is smaller. Cicadatra lorestanica doesn't have variable coloring as found in $C$. hyalina but is similar to dark brown $C$. hyalina. However, the pygofer in the new species differs in the lateral process and apical appendages of the penis are without apical processes. The aedeagus also lacks the semicircle of teeth basad to the apical appendages of $C$. hyalina. Finally, $C$. lorestanica is rather smaller than $C$. vulcania and the pygofer differs with the long and distinct dorsal beak and the larger upper lobe of pygofer.

\section{Distribution and habitat}

The species has been collected from western Iran, in Lorestan, Ilam and Hamedan provinces (Fig. 1) in woods which mainly contain Quercus spp. and a few Crataegus sp. (Fig. 7). Males and females are camouflaged on trunk and branches (Fig. 8). Their camouflage was so successful that finding and capturing silent female specimens proved to be very difficult and none were captured.

\section{Song}

Males produce their song during the hottest hours of the day (approximately 10:00 to 16:00). Each song starts with some short buzzy zht..... zht ..... etc (Fig. 9) which then continues as a steady buzz zzzzzzzzzzzzzzzzzzzht (Fig. 10). Blowing wind caused calling animals to change from a steady buzz to production of repeated short buzzy syllables. The steady buzzing resumes as soon as the wind stops. The song terminated in animals that were not physically disturbed as the steady buzz converted to some short buzzy pulses (Fig. 11). Sound pulses were produced at a rate of $917 \pm 68 \mathrm{~Hz}(n=4)$ with peak frequency determined to be $11.391 \pm 0.099 \mathrm{kHz}(\mathrm{n}=4)$. No wing clicking behavior was observed in C. lorestanica as has been described in C.atra (Olivier) and C.persica Kirkaldy (Gogala and Trilar 2003) which also inhabit Iran (Mozaffarian and Sanborn 2010).

Only a few species of Cicadatra that inhabit Iran have had their songs analyzed so comparisons are limited. The song of $C$. lorestanica is most similar to $C$. persica being a continuous series of sound pulses. However, the peak frequency of the $C$. persica song is about $8.4 \mathrm{kHz}$ with a reported range of sound pulses being produced from $670-1250 \mathrm{~Hz}$ (Gogala and Trilar 1998) so this species should be able to be differentiated easily. The continuous call of $C$. hyalina (Fabricius) is also similar but this call is rarely produced, generally in the early morning (Popov 1975; Boulard 1995). The slowly elevating intensity at the beginning of some song components also differentiates the call but the variable duration sound bursts initiating calling in some animals (Boulard 1995) is similar to that seen in $C$. lorestanica. The call of $C$. atra can be separated by the smoothly increasing intensity at the beginning of the song and a more abrupt decrease in intensity as the song terminates (Popov 19775; Boulard 1995). The song of C. platyptera Fieber is a series of individual syllables and can be easily differentiated (Boulard 1995). 


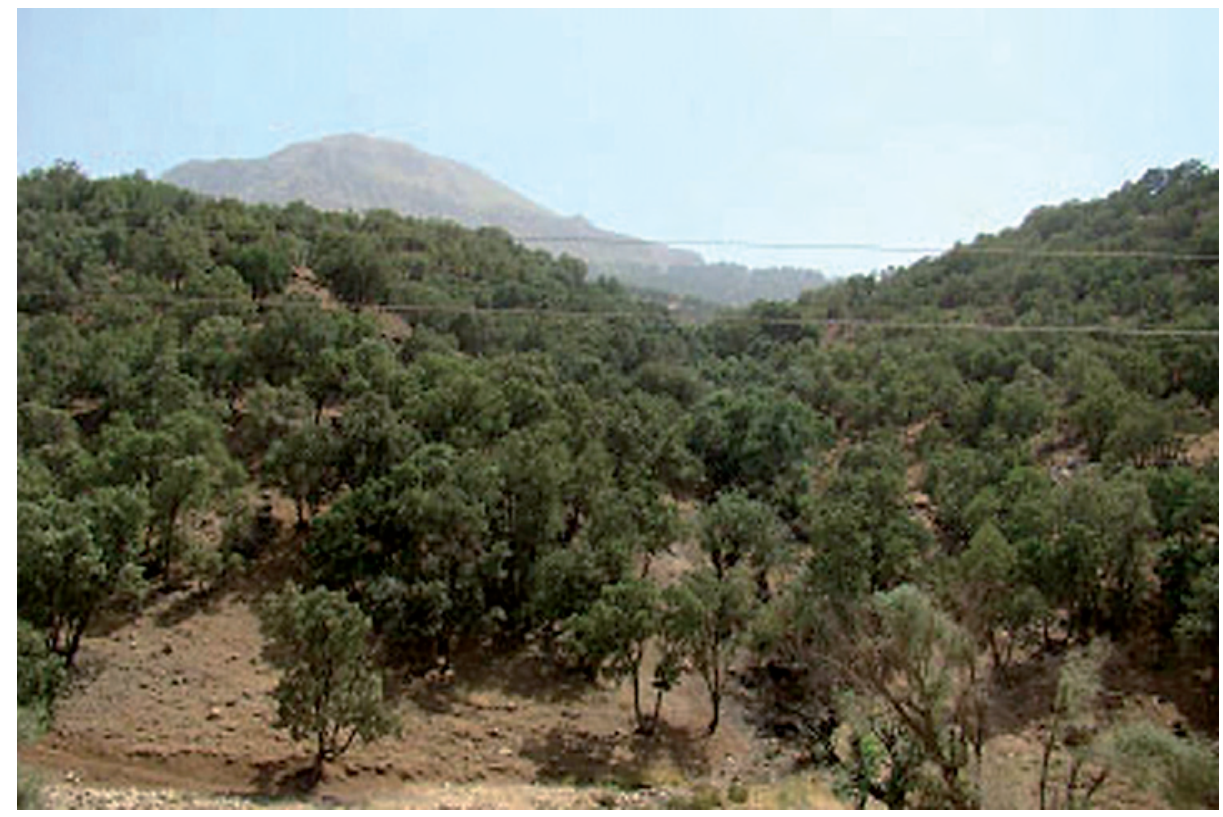

Fig. 7 - Oak wood in Nujian (Lorestan province), the collecting site of Cicadatra lorestanica.

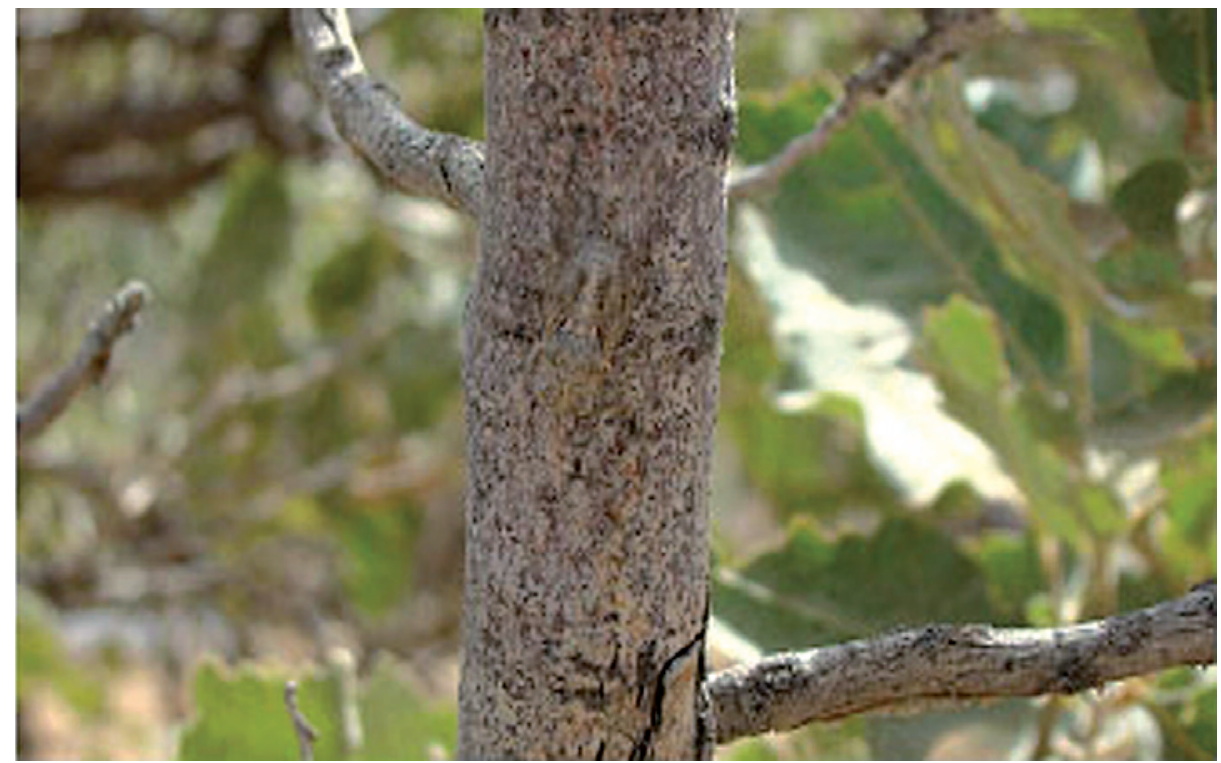

Fig. 8 - Wood of Crataegus sp. with Cicadatra lorestanica. 


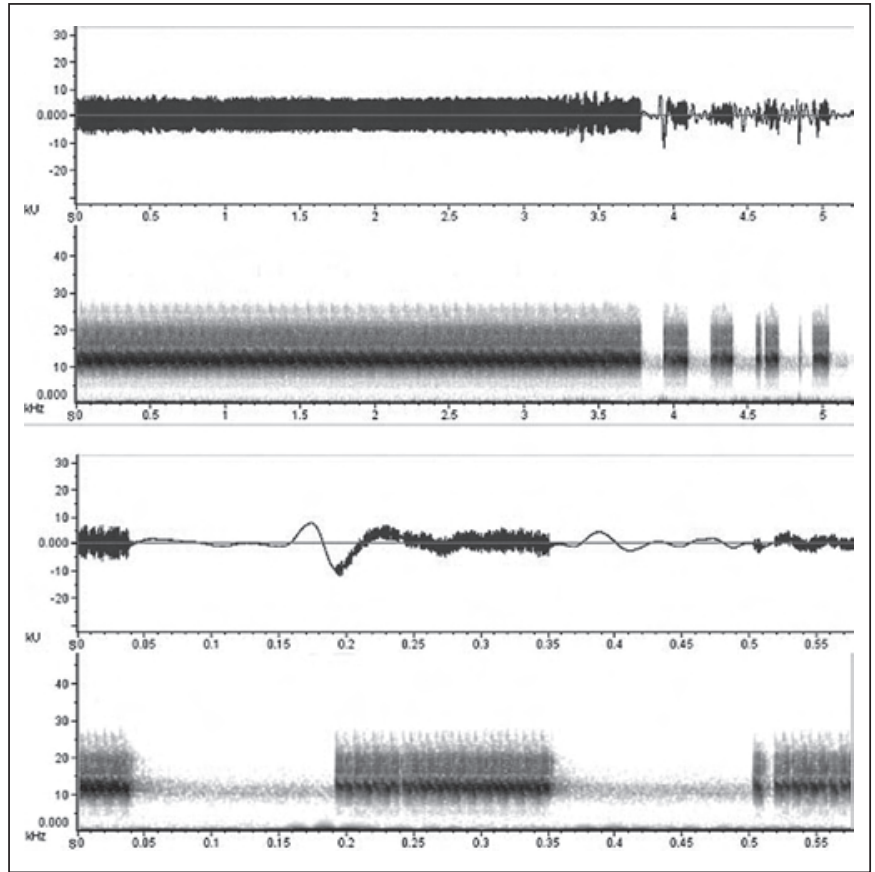

Fig. 9 - Waveform and spectrogram of a seven sec section of the starting part of the song of $\mathrm{Ci}$ cadatra lorestanica in Nujian, on 22 July 2009.

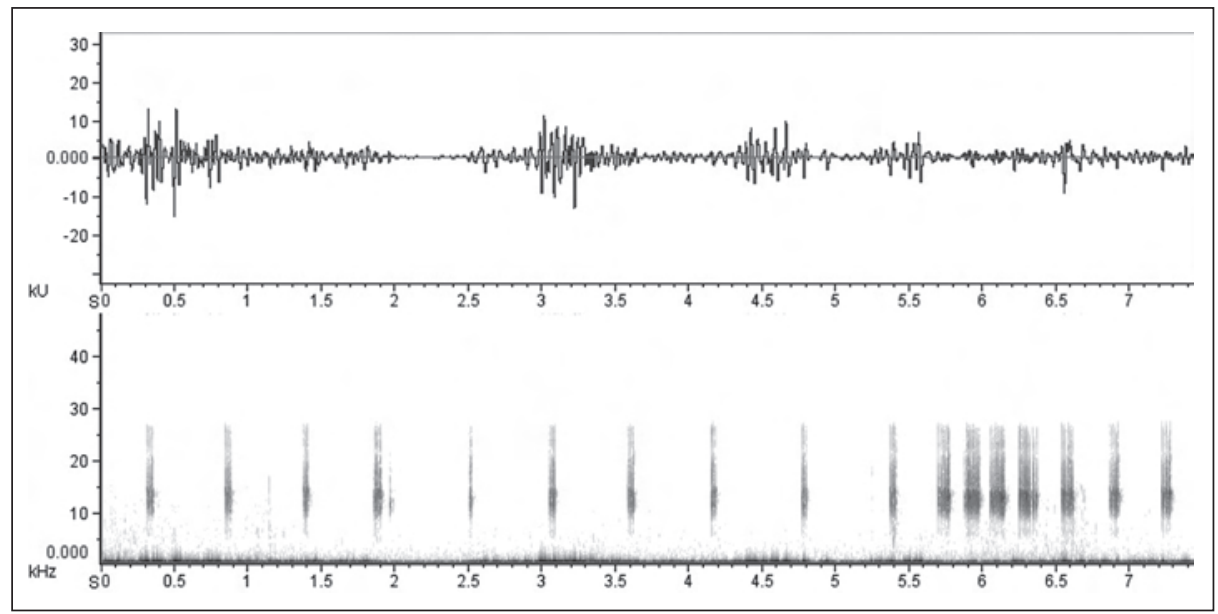

Fig. 10 - Upper trace: Waveform and spectrogram of a nine sec section of the steady buzz of the song of Cicadatra lorestanica in Nujian, on 24 July 2009. Lower trace: One sec expansion of the same song. 


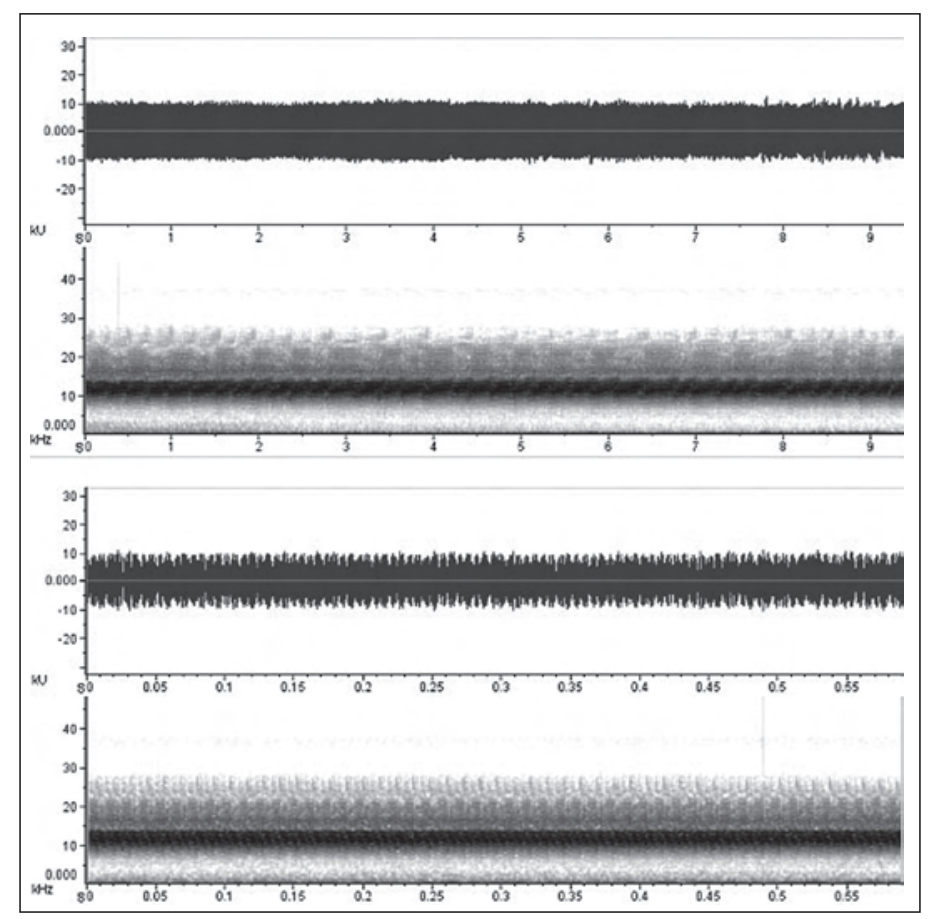

Fig. 11 - Upper trace: Waveform and spectrogram of a five sec section of the ending part of the song of Cicadatra lorestanica in Nujian, on 24 July 2009. Lower trace: One sec expansion of the song.

\section{REFERENCES}

AвAII M., 2000 - Pests of forest trees and shrubs of Iran.- Ministry of Agriculture, Agricultural Research, Education \& Extension Organization, Iran, 1-178.

BabAII H., 1967- Grape cicada, Cicadatra ochreata Melichar.- Appl. Entomol. Phytopathol., 27: 69-97.

Behdad E., 1991 - Pests of fruit crops in Iran.- Markaz-e Nashr-e Bahman, Iran, 1-822.

BOULARD M., 1995- Postures de cymbalisation, cybalizations et cartes d'identité acoustique des Cigales. 1. Généralités et espèces méditerranéennes.- ÉPHÉ Biol Evol Insectes, 7(8): 1-72.

Dlabola J., 1960 - Iranische Zikaden (Homoptera: Auchenorrhyncha) Ergebnisse der entomologischen Reisen Willy Richter, Stuttgart, in Iran, 1956, N: 31 .- Stuttg. Beitr. Naturk., 41: 1-24.

Dlabola J., 1970 - Beitrag zur Taxonomie und Chorologie einiger Palaearktischer Zikaderarten (Homoptera: Auchenorrhyncha).- Mitt. Müench. Entomol. Ges., 59: 90-107.

Dlabola J., (1979) Bahuflata gen.n neue Membraciden und Cicadiden-Arten aus dem Iran (Homoptera: Auchenorrhyncha).- Reichenbachia, 17 (28): 229-241

Dlabola J., 1981- Ergebnisse der tschechoslovakisch- iranische entomologischen Expedition nach dem Iran 1970 und 1973 (Homoptera: Auchenorrhycha), II Teil.- Acta Entomol. Mus. Nat. Pragae, 40:127-311. 
Dlabola J., 1987 - Neue ostmediterraneae und iranische Zikadentaxone (Homoptera, Auchenorrhyncha.- Acta Entomol. Bohemoslov., 84: 295-312.

Dlabola J., Heller F., 1962 - Iranische Zikaden II, Ergebnisse der entomologischen Reisen Willy Richter, Stuttagrt, im Iran 1954, No. 42.- Stuttg. Beitr.Naturk., 90: 1-8. Stuttg Beitr Naturk

FARAHBAKHSH GH., 1961 - A checklist of economically important insects and other enemies of plants and agricultural products in Iran.- Plant organization Press, Iran, 1- 153.

Gogala M., TriLAR T., 1998 - First record of Cicadatra persica Kirkaldy, 1909 from Macedonia, with description of its song.- Acta Entomol. Slov., 6: 5-15.

Gogala M., TriLAR T., 2003 - Video analysis of wing clicking in cicadas of the genera Cicadatra and Pagiphora (Homoptea: Auchenorrhyncha: Cicadoidea).- Acta Entomol. Slov., 11: 5-15.

Mirzayans A., Borumand H., ZaIRI M., RAJABI GH., 1976 - Insect fauna from province of Fars (Iran). - J. Entomol. Soc. Iran, 3(1,2): 109-135.

MiRZAYANS H., 1995 - Insects of Iran. The list of Homoptera: Auchenorrhyncha in the insect collection of Plant Pests \& Diseases Research Institute.- Plant Pests \& Diseases Research Institute, Insects Taxonomy Research Department Publication Number 1.: 59 pp.

MouLDS M. S., 2005 - An appraisal of the higher classification of cicadas (Hemiptera: Cicadoidea) with special reference to the Australian fauna.- Rec. Aust. Mus., 57: 375-446.

MozAfFarian F., 2008 - Report of Adeniana longiceps (Hem.: Auchenorrhyncha: Cicadidae) from Iran.- J. Entomol. Soc. Iran, 27 (supplement): 9-10.

MozAFfarian F., SANBORn A. F., 2010- The cicadas of Iran with the description of two new species (Hemiptera: Cicadidae).- Mitt. Mus. Naturk. Berl. - Deutsche Entomol. Z., 57(1): in press. Dtsche Entomol Z

Popov A.V., 1975 - The structure of timbals and characteristic of sound signals of singing cicadas (Homoptera, Cicadidae) from the southern regions of the USSR.- Entomol. Rev., 54: 7-35.

FARIBA MozAFFARIAN - Insect Taxonomy Research Department, Iranian Research Institute of Plant Protection, P.O. Box 1454, Tehran 19395, Iran, mozaffarian@iripp.ir, faribamozaffarian@gmail.com

Allen F. SANBORN - Department of Biology, Barry University, 11300 NE Second Avenue. Miami Shores, FL 33161-6695, USA, asanborn@mail.barry.edu

Polly K. PhILLIPS - 17446 SW 33 ${ }^{\text {rd }}$ Court, Miramar, FL 33029, USA, pkmcp31@illinoisalumni.org

Accepted 30 April 2010 